УДК 316.35

\title{
ФОРМИРОВАНИЕ ПАНДЕМОДИСКУРСА КАК СОЦИОЛОГИЧЕСКАЯ ПРОБЛЕМА
}

\author{
Корф Владислав Игоревич \\ преподаватель-исследователь кафедры управления персоналом \\ «РАНХиГС» Российская академия народного хозяйства и \\ государственной службы при Президенте Российской Федерации
}

Аннотация. В данной статье пандемодискурс, вызванный к жизни пандемией коронавируса COVID-19, рассматривается как социологическая проблема через призму научного взгляда на специфику так называемых социальных страхов населения, а также в аспекте системы демографических, гендерных, профессиональных, ролевых, психологических и других маркеров. Делается вывод о феномене пандемической ситуации, объединившей огромную часть человечества в двух контекстах одновременно - негативном и положительном.

Ключевые слова: COVID-19, пандемия, пандемодискурс, гражданское общество, государство, социологические «маркеры», социальные страхи населения, активаторы страхов.

\section{PANDEMODISCOURSE FORMATION AS A SOCIOLOGICAL PROBLEM}

\section{Korf Vladislav Igorevich}

\begin{abstract}
In this article, the pandemic discourse caused by the COVID-19 coronavirus pandemic is viewed as a sociological problem through the prism of a scientific view on the specifics of the population's so-called social fears, as well as in the aspect of the system that includes demographic, gender, professional, role, psychological and other types of markers. The conclusion is drawn about the phenomenon of the pandemic situation that has united a huge part of humanity in two contexts simultaneously - negative and positive.
\end{abstract}

Key words: COVID-19, pandemic, pandemic discourse, civil society, state, sociological «markers», social fears of the population, fear activators. 


\section{ПЕРЕДОВОЕ РАЗВИТИЕ СОВРЕМЕННОЙ НАУКИ: ОПЫТ, ПРОБЛЕМЫ, ПРОГНОЗЫ}

Объект исследования. Глобальная пандемия COVID-19 уже вписала свою страницу в мировую историю. Долгие недели самоизоляции, трагическая гибель тысяч людей, удары по мировой экономике и национальным экономическим системам, обилие негативной информации в Сети, нарастающие финансовые проблемы, нарушенные планы - все это погрузило общественное сознание в состояние радикальной неопределенности. Скоро ли откроются все предприятия и люди вернутся к полноценной работе? Как ситуация отразится на семьях, образовании, карьере? Будем ли мы снова путешествовать так же активно, как раньше? Хватит ли дотаций от центральных банков, чтобы спасти население наиболее пострадавших стран от нищеты, оказать поддержку тем, кто в ней нуждается? Эти и другие вопросы встали и перед обычными людьми, и перед политиками, вызвали ряд неоднозначных оценок и прогнозов. Определённо ясно одно: COVID-19 уже дал очень важные уроки на настоящее и будущее, ценный материал для анализа.

Цель настоящей статьи - анализ пандемодискурса как социологической проблемы через призму его «маркеров» и концепцию активации социальных страхов населения.

Использованные методы и подходы: социокультурный метод, бихевиористский (поведенческий) метод, метод экспертных оценок.

Основные результаты. Официально объявленное $\mathrm{BO}^{1}$ начало периода пандемии коронавируса COVID-19 обозначило очередной исторический перелом в существовании человечества. Коронавирус на декабрь 2020 г. продолжает возглавлять информационную повестку дня, встав в один ряд с унесшими миллионы жизней болезнями, которые давно обросли мифами в общественном сознании - от так называемой Доисторической эпидемии (около 5000 лет назад загадочная болезнь на северо-востоке Китая уничтожила огромное количество людей; остались дома, буквально набитые скелетами, что подтверждают археологические раскопки, названные «Хамин Манга»), Юстиниановой чумы (541-750 гг. н.э.; это первая официально идостаточно детально задокументированная пандемия чумы в годы правления византийского императора Юстиниана I, охватившая часть мира и

1 ВОЗ объявила пандемию коронавируса в мире. Коммерсантъ. 11 марта 2020. 11.03.2020, 19:32. https://www.kommersant.ru/doc/4284473 


\section{ПЕРЕДОВОЕ РАЗВИТИЕ СОВРЕМЕННОЙ НАУКИ: ОПЫТ, ПРОБЛЕМЫ, ПРОГНОЗЫ}

напоминавшая о себе в течение двух веков, погибших было около 90000 000) до эпидемии чумы в России 1770-1772 гг. (уничтожила в одной Москве до 100000 человек), Третьей пандемии чумы 1855-1960 гг. (только в Китае и Индии жертв было, по экспертным оценкам, не менее 12000 000), Натуральной оспы 1877-1977 гг. (погибших около 500000000 человек на всей планете, последняя смерть от оспы зафиксирована в 1978 г.), эпидемии ВИЧ (с 1980 г.; ВИЧ/СПИД на сегодняшний день унес жизни уже более 35000000 человек) $)^{2}$. Коронавирус закономерно разделил жизни людей затронутых им стран на «до» и «после». Объект его воздействия явно не один: это не только собственно тело заболевшего человека, но и (социологически, психологически, когнитивно) сознание, психика, поведение, нервная система тех, кто находится в сфере пандемодискурса, под влиянием живой коммуникации, СМИ и рефлексии.

Теперь, оглядываясь назад, можно наблюдать, как волнообразно понедельно в условиях пандемии начали нарастать социальные страхи населения. Страх - неотъемлемая часть истории человечества, феномен, отраженный в науке и культуре. На протяжении эволюции общества страх трансформируется со стороны вызывающих его объектов: от древнего осознания естественно-природных катаклизмов, потусторонних сил, могущественных духов, божеств до государственной машины, правителей, самой социальной организации. На современном этапе доминируют социальные страхи, вызываемые техногенными катастрофами, коммуникациями, экономическими кризисами, терроризмом, то есть реалиями XXI века. Без рассмотрения социальных страхов невозможно полноценное социологическое осмысление риск-факторов, пронизывающих все уровни современности.

Закономерно, что массовая активизация страхов происходит в периоды резких переломов, трансформаций социальной организации жизни, переоценок базовых ориентиров. Запущенный механизм пандемодискурса принудил каждого члена социума заняться просчетом возможных угроз в условиях ограниченных, противоречивых, разрозненных знаний о возможных вариантах разрешения ситуации. Пандемодискурс включил в себя различные «векторы» развития кризисного сценария. Назовем наиболее значимые из них:

\footnotetext{
2 От чумы до коронавируса: история эпидемий и пандемий. https://www.popmech.ru/science/562194-otchumy-do-koronavirusa-istoriya-epidemiy-i-pandemiy/
} 


\section{ПЕРЕДОВОЕ РАЗВИТИЕ СОВРЕМЕННОЙ НАУКИ: ОПЫТ, ПРОБЛЕМЫ, ПРОГНОЗЫ}

1. Официальные заявления от гоструктур, высших политиков, а также проводящие государственную линию СМИ.

2. Сведения от свободных, независимых СМИ.

3. Свободный обмен информацией пользователей в социальных сетях (от позитива до негатива, слухов и домыслов, фейков, «чёрного юмора» и др.). Заполнение интернет-сети так называемыми «прецедентными» текстами, часть из них - апокалиптической направленности.

4. Рост популярности «домашнего», личностного контента: «кукингов», «семейного» видео; концентрация в условиях самоизоляции на «вечных ценностях»: семья, дом, отношения с близкими людьми, значение взаимной поддержки, простые радости жизни, возможность сосредоточиться на любимом хобби, прочитать книги и посмотреть фильмы, до которых давно не доходили руки, и т.д., дистанционные курсы, спорт дома, живопись дома, хэндмейд дома, спа дома и др.

5. Широкое «пандемотворчество» (изо-изоляция, неомифология, неофольклор, многочисленные мемы, неологизмы - например, новое слово «коронавты», то есть врачи, работающие в «красной зоне»).

6. Увеличение количества виртуальных взаимодействий в условиях «отрезанности» от нормального социального общения. Пандемия дала миллионам людей нечто существенно общее, и это привело к более тесным воссоединениям, пусть даже на расстоянии. Коммуникация зачастую стала более содержательной, глубокой.

7. Рост стрессовости групп населения. Патопсихологическими «триггерами» запущенных модификаций послужили такие состояния, как раздражение, тревога перед настоящим и будущим, одиночество, паника, болезненность, обречённость ${ }^{3}$. Негативные последствия самоизоляции для психики (отсутствие физических контактов, перемещений, обилие негативных новостей и ухудшение экономической ситуации) привели к тому, что многие люди начали испытывать повышенную тревожность, в ряде стран, в том числе в России, произошел рост случаев домашнего насилия.

8. Отдельное направление пандемодискурса - тема пандемии в научных публикация $\mathrm{x}^{4}$. В изученном аналитическом материале исходными данными

\footnotetext{
${ }^{3}$ Яковлев А. Пандемия паники: насколько на самом деле страшен новый коронавирус. 6 февраля 2020 г. Подробнее на РБК: https://www.rbc.ru/opinions/society/06/02/2020/5e3a89b49a794718f3b13d70

4 «Пандемия» научных публикаций о COVID-19. 22 декабря 2020. https://habr.com/ru/post/493512/
} 
послужили сведения о более чем 10000 академических публикациях, собранных к 22 декабря 2020 года при помощи поисковой системы Google Scholar.

Масштабы корона-опасности, ее многоуровневость прямо сказались на характере страха и его социальной обусловленности, вызвали нарастание депрессий, различных девиаций, агрессии, подавленности, суицидального синдрома и других проявлений, образовав негативный полюс. В рамках пандемодискурса выделились и начали взаимодействовать друг с другом демографические, гендерные, профессиональные, ролевые, психологические и другие «маркеры» (социальная дифференция общества по степени прямой угрозы, профессиональных перспектив, психологической устойчивости и целому ряду других параметров). Социальные страхи предстали как многоуровневый комплекс, в негативных своих проявлениях понижающий качество жизни, деморализующий, обессиливающий человека, вредящий обществу в целом. Пандемодискурс непосредственно затронул жизненные стратегии личности, ее настроение и поведение в усложненных социальных условиях, выявил преобладающие страхи применительно к социальным группам по вектору направленности, формам, силе выражения (например, окончание школы и поступление в вуз у выпускников, содержание детей, дома и семьи у родителей, страх остаться без пенсии и минимальных средств защиты у пожилых людей). Социальными источниками распространения социальных страхов у населения послужили СМИ, интернет, опосредованный опыт «средового», близкого окружения, а также непосредственный опыт. При этом на первый план вышла прогностическая функция страха - боязнь перед будущим. На наш взгляд, амбивалентность пандемической ситуации проявилась в том, что, с одной стороны, она выступила активатором деструктивных социальных страхов, с другой - вызвала к жизни общественные и индивидуальные механизмы противодействия.

Заключение. Пандемия COVID-19 в очередной раз показала, что даже самые образованные, знающие, мыслящие, эрудированные люди не обладают всей полнотой информации, чтобы делать точные прогнозы. Несмотря на то что пандемическая ситуация общая, интернациональная, многие оказались с ней «один на один», когда человек сосредотачивается не на широких масштабах, а на своей отдельно взятой жизни: нехватке денежных средств, потере работы, нестабильности, проблемах со здоровьем и др. Как принято говорить в таких случаях, мир уже не будет прежним. Ситуация останется в умах и душах 
людей, в их памяти, в семьях, в статистике стран, придется преодолевать ее влияние на мировую и национальные экономики.

Вместе с тем толчок получила наука, система IT, в частности, в области эффективных форм дистанционного образования и пр. Кризис дал глобализованному человечеству новые возможности в более гибких способах использования существующих технологий, а также в возросшем единстве духа, в борьбе со стрессами и угрозами с помощью солидарности и концентрации на «вечном», поистине ценном. Пандемодискурс выступил как мощный фактор трансформации сознания, деятельности, психики, поведения человека и т.д., стал внушительным напоминанием о том, что основной политической, экономической и социальной «единицей» остается национальное государство, которое в критической ситуации обязано бросить все силы (и экономические, и духовные) на защиту своего населения, максимально взять под контроль негативные эмоции.

\section{Список литературы}

1. ВОЗ объявила пандемию коронавируса в мире. Коммерсантъ. 11 марта 2020. 11.03.2020, 19:32. https://www.kommersant.ru/doc/4284473

2. «Дезинформационная пандемия»: М. Захарова отреагировала на статью FT о смертности от коронавируса в России. Представитель МИД назвала коронавирусную инфекцию «питательной средой» для дезинформационных кампаний. https://www.kp.ru/online/news/3868833/

3. От чумы до коронавируса: история эпидемий и пандемий https://www.popmech.ru/science/562194-ot-chumy-do-koronavirusa-istoriyaepidemiy-i-pandemiy/

4. «Пандемия» научных публикаций о COVID-19. 22 марта 2020. https://habr.com/ru/post/493512/

5. Яковлев А. Пандемия паники: насколько на самом деле страшен новый коронавирус. 6 февраля 2020 г. Подробнее на РБК: https://www.rbc.ru /opinions/society/06/02/2020/5e3a89b49a794718f3b13d70

(C) В.И. Корф, 2020 